International Journal of Engineering \& Technology, $7(4.5)(2018) 693-695$
SPC
International Journal of Engineering \& Technology
Website $\frac{w w w . s c i e n c e p u b c o . c o m / i n d e x . p h p / I J E T}{2}$
Research paper

\title{
Properties of geopolymer pervious concrete made with GGBS
}

\author{
Ramesh Babu Chokkalingam ${ }^{1 *}$, Prakkash Subbu L ${ }^{2}$, Thangavel Raj R ${ }^{2}$, Shubham Sawant $M^{2}$ \\ ${ }^{1}$ Associate Professor \& Head, Department of Civil Engineering, Kalasalingam Academy of Research and Education, Anand Nagar, \\ Krishnankoil - 626 126, Virudhunagar District, Tamilnadu, India \\ ${ }^{2}$ B. Tech. Final Year, Department of Civil Engineering, Kalasalingam Academy of Research and Education, Anand Nagar, Krishnankoil \\ - 626 126, Virudhunagar District, Tamilnadu, India \\ *Corresponding author E-mail: c.rameshbabu@klu.ac.in
}

\begin{abstract}
Pervious concrete is a light weight concrete containing voids in the range of 14 to $31 \%$. The usage of pervious concretes has been increased due to its merits on pollution control and environmental considerations. The pervious concretes are also used to reduce the storm water runoff and recharges the underground water table. Eventhough the pervious concrete has lot of merits, it also has consider- able demerits related to strength issues. In order to achieve the strength high cement content mixes may be incorporated which is not a viable solution. In this paper, geopolymer technology has been used to develop pervious concrete. Geopolymer pervious concrete is pro- duced using GGBS as raw material and sodium hydroxide and sodium silicate as activator solution. Five mixes have been developed with varying GGBS content of $450,460,470,480$ and $490 \mathrm{~kg} / \mathrm{m} 3$. The cement to aggregate ratio is fixed at 1:3 for all the mixtures and the water cement ratio is kept constant at 0.3 . The compressive strength revealed that strength of around $20 \mathrm{MPa}$ was attained for all the mixtures and strength increases with respect to the increase in GGBS content. There was not significant changes in the permeability property since the aggregate cement ratio is maintained for all the mixtures.
\end{abstract}

Keywords: GGBS; Geopolymer; Sodium Silicate; Sodium Hydroxide; Permeability.

\section{Introduction}

Pervious concrete is a light weight concrete consisting of coarse aggregate, Portland cement, and water. The typical air voids reported for pervious concrete mixes in the United States range from 14 to $31 \%$ [1]. A multitude of experiments have been performed by several researchers on pervious concrete. Malhotra [2] performed experiments on pervious concrete to find the corre- lation between compressive strength and mix design parameters. $\mathrm{He}$ concluded that compressive strength depends on the water cement ratio and the aggregate cement ratio. Meninger [3] per- formed various tests on pervious concrete by varying the parame- ters such as water cement ratio, aggregate cement ratio, compac- tion and curing time. The results obtained were similar to those of Malhotra. Meninger also found that the compressive strength of pervious concrete was found to be less than conventional concrete and should be utilized in areas restricted to automobile use and light duty areas. Huang et al. [4] studied the permeability and strength properties of polymer modified pervious concrete. They suggested that it was possible to produce pervious concrete with acceptable permeability and strength through the combination of latex and sand. Shu et al. [5] compared the performance of laboratory and field produced pervious concrete mixtures. Their results showed that the pervious concrete mixtures made with latex exhibited lower porosity and permeability, higher compressive and split tensile strengths, and higher abrasion resistance than those without latex. They also suggested that properly designed and laboratory verified pervious concrete can meet the requirements of permeability and strength properties in the field. Tho-in et al. [6] evaluated the performance of pervious concrete made of high calcium fly ash geopolymer binder. They stated that geopolymer satisfactory mechanical properties. Sata et al. [7] studied the performance of pervious geopolymer concrete using recycled aggregate. They stated that it is feasible to use Recycled concrete (RC) and Recycled brick (RB) as recycled coarse aggregates with highcalcium fly ash geopolymer binder for making pervious concrete with acceptable properties. However, they also stated that the using RC and RB resulted in significant losses in strength as compared to a natural aggregate pervious concrete. Ibrahim et al. [8] studied the performance of pervious concrete by varying the parameters such as coarse aggregate size, coarse aggregate volume, water-to-cement ratio, and cement content. They found that the average water permeability coefficient of pervious concrete produced from poor graded coarse aggregate is approximately 0.021 $\mathrm{m} / \mathrm{s}$.

From the International perspective, it has been observed that lot of work has been done of pervious concrete. But work on geopolymer pervious concrete is limited, which has to be strength- ened by performing research related to that field. This research paper mainly aims at developing geopolymer pervious concrete with GGBS as raw material and sodium hydroxide and sodium silicate as activator solution and studying its mechanical and per- meability properties.

\section{Materials used}

Ground granulated blast furnace slag procured from locally available vendor has been used for the entire study. The chemical composition of GGBS was analysed using XRay florescence test. The results of the XRF analysis are shown in Table 1 and Figure 1 respectively. Coarse aggregate of nominal maximum size $20 \mathrm{~mm}$ used in this investigation have been procured locally from Srivilli- 
puthur, Tamilnadu, India. Aggregate properties, specific gravity, bulk density and sieve analysis are determined as per the procedures mentioned in IS 2386 (shown in Table 2 and 3). Commercially available Polycarboxylate based high range water reducer was used to maintain the workability in the concrete mix.

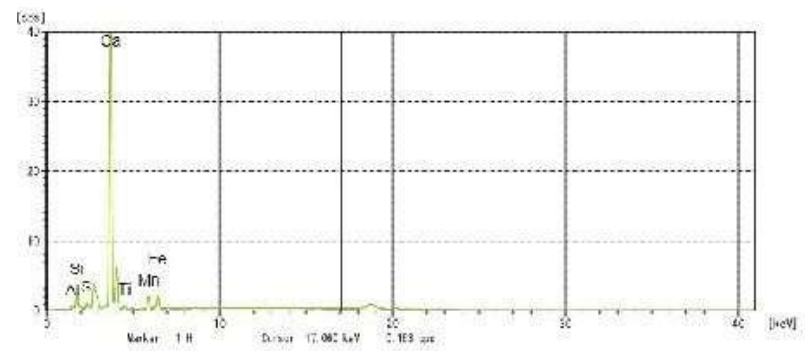

Fig. 1: XRF Analysis of GGBS.

Table 1: XRF Analysis of Clinkers and Gypsums Used in the Study

\begin{tabular}{ll}
\hline Oxides & GGBS \\
\hline $\mathrm{SiO}_{2}$ & 29.929 \\
$\mathrm{Al}_{2} \mathrm{O}_{3}$ & 10.968 \\
$\mathrm{Fe} 2 \mathrm{O} 3$ & 1.084 \\
$\mathrm{CaO}$ & 52.388 \\
$\mathrm{TiO}_{2}$ & 1.498 \\
$\mathrm{MnO}_{2}$ & 1.707 \\
$\mathrm{SO}_{3}$ & 2.427 \\
\hline
\end{tabular}

Table 2: Properties of Coarse Aggregates

\begin{tabular}{ll}
\hline Coarse aggregate & $20 \mathrm{~mm}$ \\
\hline Specific gravity & 2.80 \\
Water absorption, $\%$ & 0.40 \\
\hline
\end{tabular}

Table 3: Sieve Analysis of Coarse Aggregate

\begin{tabular}{llll}
\hline IS sieve & $\begin{array}{l}\text { Weight retained } \\
(\mathrm{g})\end{array}$ & $\begin{array}{l}\text { Cumulative \% re- } \\
\text { tained }\end{array}$ & Cumulative \% passing \\
\hline 40 & 0 & 0 & 100 \\
20 & 1406 & 46.17 & 53.13 \\
10 & 1520 & 97.53 & 2.47 \\
4.75 & 74 & 100 & 0 \\
\hline
\end{tabular}

\subsection{Mix proportions}

All geopolymer pervious concrete (GPC) mixtures were produced with GGBS to aggregate ratio of $1: 3$ by weight. The $\mathrm{Na} 2 \mathrm{SiO} / \mathrm{NaOH}$ ratio and alkali liquid/GGBS ratio were kept constant at 2.5 and 0.3 respectively. The molarity of $\mathrm{NaOH}$ was kept constant at $12 \mathrm{M}$ for all the mixtures. The proportions of various GPC mixtures used in this investigation are shown in Table 4

Table 4: Mix Proportion for GPC Concrete

\begin{tabular}{|c|c|c|c|c|}
\hline $\begin{array}{ll}\text { Mix ID } \begin{array}{l}\text { GGBS con- } \\
\text { tent, } \mathrm{kg} / \mathrm{m}^{3}\end{array}\end{array}$ & $\begin{array}{l}\text { Coarse aggre- } \\
\text { gate, } \mathrm{kg} / \mathrm{m}^{3}\end{array}$ & $\begin{array}{l}\mathrm{NaOH} \\
\mathrm{lit} / \mathrm{m}^{3}\end{array}$ & $\begin{array}{l}\mathrm{Na}_{2} \mathrm{SiC} \\
\mathrm{lit} / \mathrm{m}^{3}\end{array}$ & $\begin{array}{l}\text { 3Admixture, } \\
\mathrm{kg} / \mathrm{m}^{3}\end{array}$ \\
\hline GPC450450 & 1350 & 39 & 96 & 2.7 \\
\hline GPC460460 & 1380 & 39 & 99 & 2.76 \\
\hline GPC470470 & 1410 & 40 & 101 & 2.82 \\
\hline GPC480480 & 1440 & 41 & 103 & 2.88 \\
\hline GPC490490 & 1470 & 42 & 105 & 2.94 \\
\hline
\end{tabular}

\subsection{Mixing, curing and casting}

The sodium hydroxide and sodium silicate solutions of desired quantity were mixed together about 24 hours prior to the mixing of other ingredients to accelerate the reactivity of the alkaline solution. Concrete ingredients were mixed in a laboratory pan mixer until a uniform mixing is achieved. The concrete were then casted in cubes and cylinders and kept undisturbed for 24 hours. After 24 hours, the moulds were removed and stored at room temperature till the date of testing.

\subsection{Testing methods}

The compressive strength was performed on $150 \times 150 \mathrm{~mm}$ cubes at 7 and 28 days respectively as per IS 5161989 . The split tensile test was performed on 100x200mm at 28 days as per IS 5161989 . Flexural strength was carried out on $100 \times 100 \times 500 \mathrm{~mm}$ prism as per IS 516 1989. The results discussed in the subsequent section are average of three readings. Permeability test was conducted on $100 \times 200 \mathrm{~mm}$ cylinders as per falling head permeability method. The surfaces are covered with polythene sheets as shown in figure and time is noted for particular measure of water. The experimental setup for measuring the permeability test is shown in Figure 2. Figure 3 and 4 shows the cylinder sample used for split tensile test and flexural strength of GPC respectively.

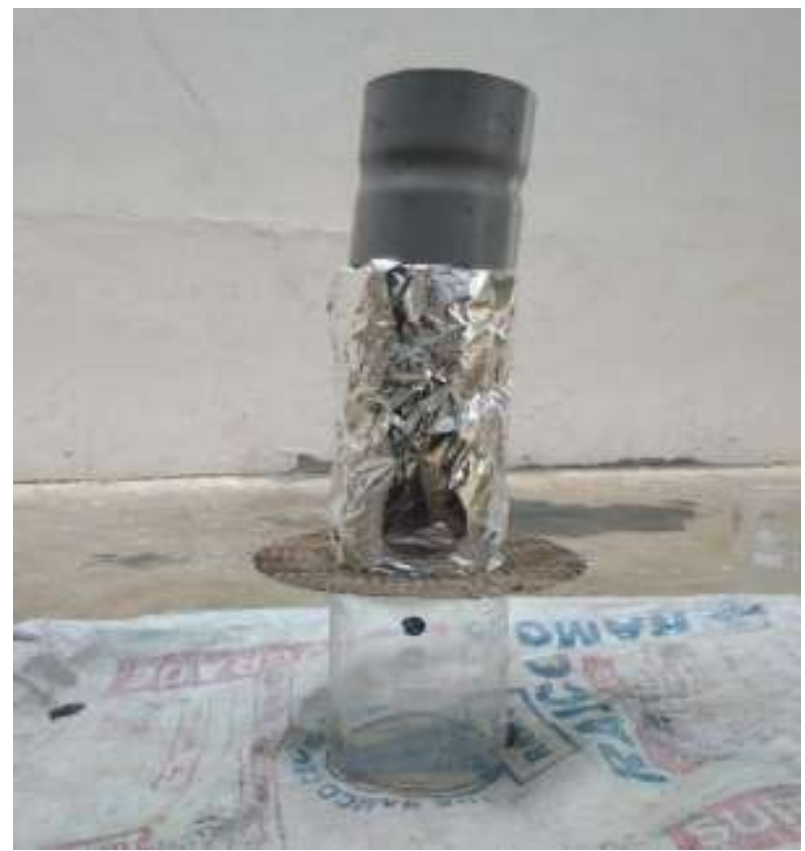

Fig. 2: Experimental Setup for Measuring Permeability.

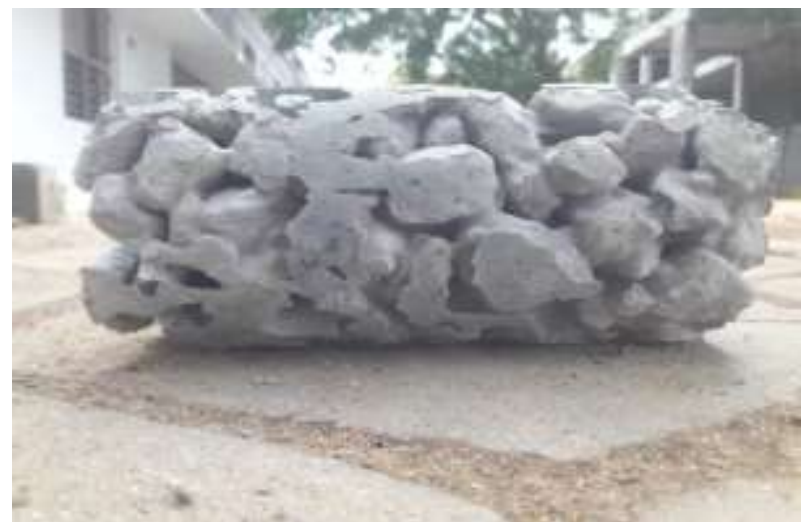

Fig. 3: Cylinder Used for Split Tensile Test.

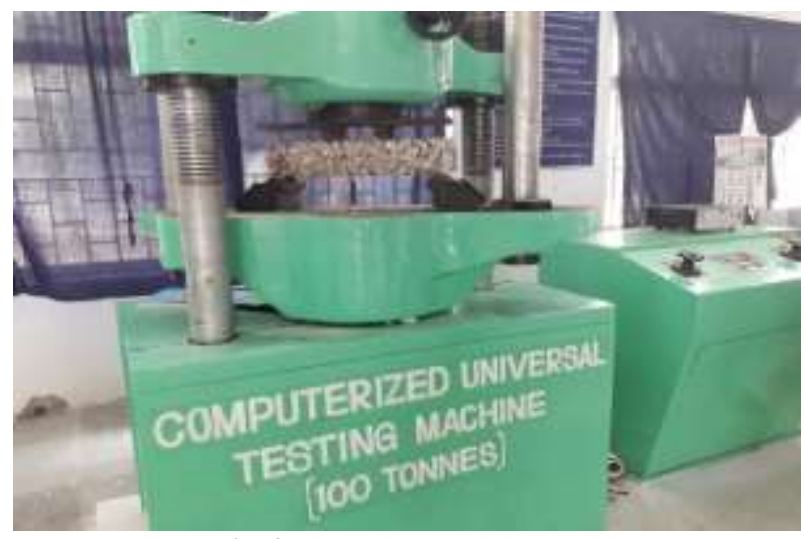

Fig. 4: Flexural Strength for GPC. 


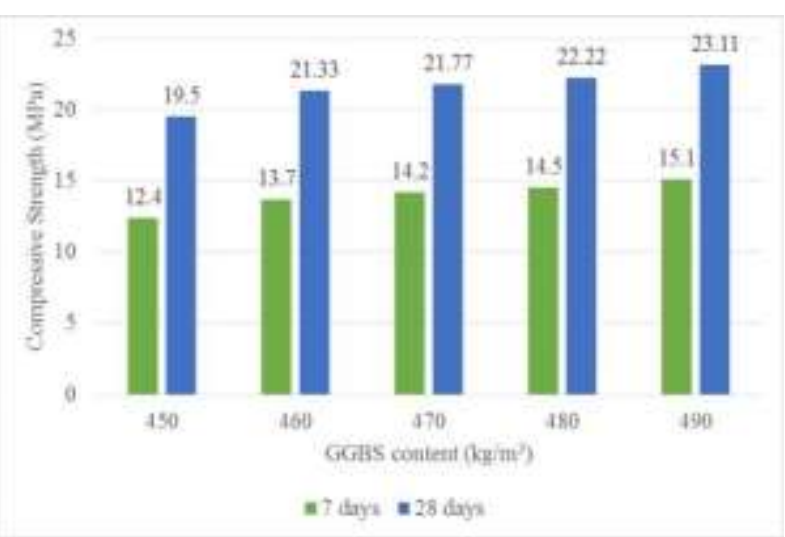

Fig. 5: Compressive Strength of GPC Mixtures.

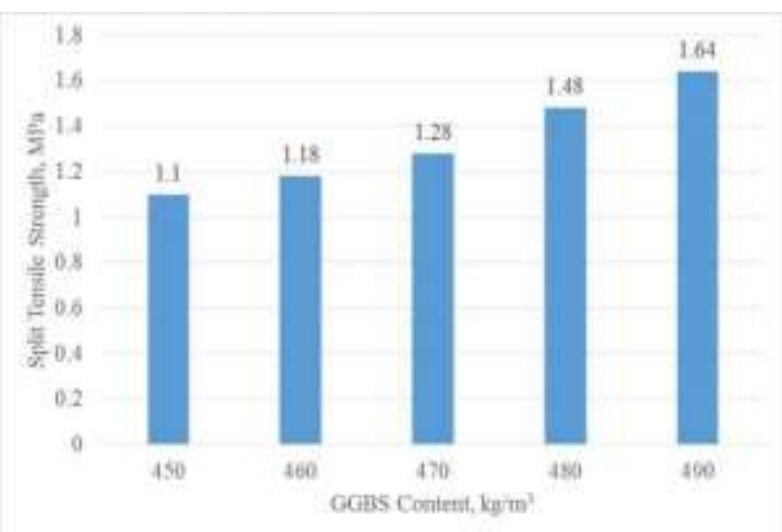

Fig. 6: Split Tensile Strength of GPC Mixtures.

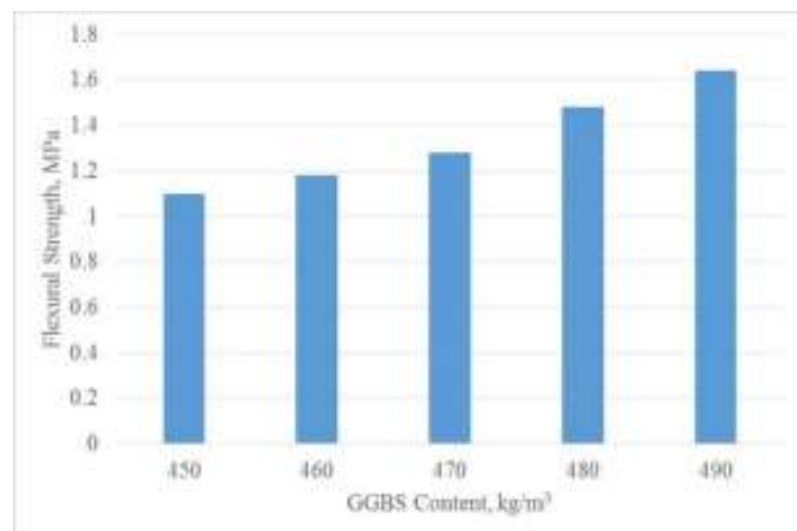

Fig. 7: Flexural Strength of GPC Mixtures.

\section{Results and discussion}

\subsection{Effect of GGBS content on the compressive strength}

Figure 5 shows the compressive strength results of GPC concretes with various GGBS contents at 7 and 28 days respectively. From the 7 days compressive strength results it is been observed that there is slight increase in the strength of GPC mixes with respect to change in GGBS content from 450 to $490 \mathrm{~kg} / \mathrm{m} 3$. The strength increase was around $20 \%$ from change of GGBS content from 450 to $490 \mathrm{~kg} / \mathrm{m} 3$. The strength was increased around $50 \%$ from 7 days to 28 days for all the mixtures. Figure 7 shows the split ten- sile strength results of GPC mixtures at 28 days. The split tensile strength followed the same trend as that of compressive strength. The split tensile strength results varied from $0.6 \mathrm{MPa}$ to $1.03 \mathrm{MPa}$ by varying the GGBS content from 450 to $490 \mathrm{~kg} / \mathrm{m} 3$. Figure 8 shows the flexural strength of GPC concretes at 28 days for different GGBS contents. The flexural strength also followed the same trend as that of compressive strength results.
Table 5: Penetration Time of GPC Mixtures

\begin{tabular}{ll}
\hline Mix ID & Penetration time ( $\mathrm{sec}-$ onds/lit) \\
\hline GPC450 & 20 \\
GPC460 & 19 \\
GPC470 & 18 \\
GPC480 & 17 \\
GPC490 & 16 \\
\hline
\end{tabular}

Table 5 shows the penetration time of all GPC mixtures at 28 days for one litre of water. It is been observed that for $450 \mathrm{~kg} / \mathrm{m} 3$ the penetration time is 20 seconds and it is reduced with respect to the increase in GGBS content. It is obvious that more cementitious content may fill the voids and results in the reduction in the permeability properties which is evident from the results of penetration time test.

\section{Conclusion}

The following conclusion can be drawn from the investigation carried out on GPC mixtures

- The compressive strength of all GPC mixtures was around $20 \mathrm{MPa}$ at the age of 28 days, which is more positive for using the GPC mixtures for pavement appli- cations

- The compressive strength increases with increase in GGBS content, but the increase in not significant due to the porous nature of the concrete

- The split tensile strength and flexural strength follows the same trend as that of compressive strength

- The permeability test revealed that permeability increas- es with decrease in cementitious content and vice versa

\section{Acknowledgements}

The authors are grateful to Tamilnadu State Council for Science and Technology for funding this project under student project scheme 2017-18 under environmental science stream.

\section{References}

[1] American Concrete Institute (ACI 2010) Report on per- vious concrete, ACI 522-R-10, ACI Farmington Hills, MI.

[2] Malhotra, V. M.(1976) No fines concrete, its properties and applications, ACI Journal, Vol 73, 11, pp 628 -644.

[3] Meininger, Richard C., (1988) No fines pervious con- crete for paving, Concrete International, Vo1 10, 8, pp20-27.

[4] Huang, B., H. Wu, X. Shu and E.G. Burdette (2010) La- boratory evaluation of permeability and strength of pol- ymer modified pervious concrete, Construction and Building Materials, 24, pp 818823.

[5] Shu, X., B. Huang, H. Wu, Q, Dong and E.G. Burdette (2011) Performance comparison of laboratory and field produced pervious concrete mixtures, Construction and Building Materials, 25, pp 3187-3192.

[6] Tho-in, T., V. Sata, P. Chindaprasirt, C. Jaturapitakkul (2012) Pervious high calcium flyash geopolymer con- crete, Construction and Building Materials, 30, pp 366- 371.

[7] Sata, V., A. Wongsa and P. Chindaprasirt, (2013) Prop- erties of pervious geopolymer concrete using recycled aggregate, Construction and Building Materials, 42, pp 33-39.

[8] Ibrahim, A., E. Mahmoud, M. Yamin and V.C. Pati- bandla, (2014) Experimental study on Portland cement pervious concrete mechanical and hydrological proper- ties, Construction and Building Materials, 50, pp 524- 529.

[9] IS 383, Specification for Coarse and Fine Aggregate from Natural Sources for Concrete, Bureau of Indian Standards, New Delhi, India.

[10] IS 516-1959, Methods of Tests for Strength of Concrete, Bureau of Indian Standards, New Delhi, India.

[11] IS 2386, Methods of Test for Aggregate in Concrete, Bureau of Indian Standards, New Delhi, India

[12] Chokkalingam, RB and Ganesan N, A Study on the development of geopolymer concrete using flyash, International Journal of Engineering and Technology (UAE), Vol 6, 4, 2017, pp 163-167. 